\title{
PEMANFAATAN APLIKASI JAVA UNTUK MENINGKATKAN PENGUASAAN KOSA KATA ANAK USIA DINI
}

\author{
Yulian Dinihari ${ }^{1}$, Dian Nazelliana ${ }^{2}$, Purwanti $^{3}$ \\ Universitas Indraprasta PGRI \\ yulian.dinihari@unindra.ac.id ${ }^{1}$ \\ dian.nazelliana@unindra.ac.id², \\ purwanti@unindra.ac.id ${ }^{3}$
}

\begin{abstract}
ABSTRAK
Kemahiran berbahasa tidak terlepas dari penguasaan kosa kata. Penguasaan kosakata dapat memengaruhi kemampuan berekspresi, mengungkapkan ide, dan berpikir kritis. Tujuan penelitian ini adalah untuk meningkatkan kemampuan kosa kata anak usia dini di RA AtTaqwa, Jakarta Pusat menggunakan aplikasi java. Metode yang digunakan adalah Penelitian Tindakan Kelas. Hasil dari penelitian ini terdapat peningkatan kosa kata anak pada setiap siklusnya. Hal tersebut terbukti pada siklus I, penguasaan kosa kata BB 11\%, MB 52\%, BSH $28 \%$, BSB $21 \%$. Hasil siklus II naik seperti apa yang sudah diharapkan yaitu kenaikan kosa kata anak sebanyak lebih dari 50\%, BB 0\% MB 5\%, BSH 26\%, BSB 74\%. Program java layak untuk digunakan sebagai media belajar, media belajar ini mampu untuk meningkatkan kemampuan kosa kata anak.
\end{abstract}

Kata kunci: Penguasaan Kosa Kata, Aplikasi Java

\section{A. PENDAHULUAN}

Teknologi saat ini semakin canggih dengan ditandai adanya revolusi industri 4.0. Maka, dalam bidang pendidikan telah banyak dilakukan inovasi untuk memberikan kemudahan pada peserta didik dalam memahami materi pembelajaran. Selain itu, peserta didik sangat tertarik dengan adanya media pembelajaran yang beragam dan inovatif yang digunakan oleh para guru. Salah satu contoh media yang dapat digunakan guru yaitu media animasi dan multimedia interaktif. Hal itu, menarik minat peserta didik khususnya anak usia dini dalam pembelajaran. Mereka sangat tertarik dengan hal-hal yang baru yang diajarkan oleh para guru. Melalui media pembelajaran yang menarik, maka anak usia dini akan lebih memerhatikan apa yang sudah diajarkan oleh guru di kelas sehingga proses belajar di kelas menjadi hal yang menyenangkan.

Terkait dengan hal tersebut, hasil observasi peneliti yaitu rendahnya kemampuan berbahasa anak dalam pemerolehan kosa kata anak usia dini di RA At-Taqwa Jakarta Pusat. Anak-anak usia dini sering salah dalam mengucapkan kosakata. Selain itu, mereka juga sulit dalam memilih kosa kata untuk mengungkapkan sesuatu. Keinginan bertanya dalam proses 
Lingua Rima: Jurnal Pendidikan Program Studi Bahasa dan Sastra Indonesia

Vol. 9 No. 1 Juli 2020

pembelajaran pun masih rendah.

Rendahnya kemampuan bahasa anak usia dini di RA At-Taqwa, Jakarta Pusat disebabkan pendekatan pembelajaran yang kurang menarik, komunikasi yang kurang hangat antara guru dengan siswa, dan media pembelajaran yang kurang variatif dalam pembelajaran bahasa pada anak usia dini. Metode yang digunakan di RA At-Taqwa, Jakarta Pusat tersebut masih menggunakan metode ceramah yang membuat anak menjadi bosan dan kurang aktif dalam pembelajaran.

Untuk memecahkan masalah tersebut, diperlukan media pembelajaran yang tepat agar nantinya anak usia dini dapat menguasai penguasaan kosa kata yang tepat. Salah satu program komputer yang tepat untuk pembelajaran anak usia dini adalah aplikasi java. Menurut Garling dan Lestari (2010:1) dalam artikel (Sallaby, Utami, \& Arliando, 2015) Java adalah sebuah bahasa pemrograman scripting yang sering digunakan dalam pembuatan aplikasi berbasis handphone dan juga dapat digunakan untuk menyediakan akses objek yang disisipkan di aplikasi lain.

Aplikasi java berfungsi sebagai penambah tingkah laku agar widget dapat tampil lebih atraktif. Aplikasi java dinilai mampu untuk menjawab kebutuhan peserta didik, dalam hal ini adalah anak usia dini. Aplikasi java ini mampu memberikan kemudahan bagi anak usia dini untuk memahami kosa kata baru. Mereka dapat mengembangkan kosa kata baru dan dapat cepat memahami kosa kata baru.

Penelitian ini bertujuan untuk meningkatkan penguasaan kosa kata peserta didik usia dini di RA At-Taqwa Jakarta Pusat melalui aplikasi java. Maka, judul penelitian ini "Pemanfaatan Aplikasi Java untuk Meningkatkan Penguasaan Kosa Kata Anak Usia Dini di Era Revolusi Industri 4.0”

\section{B. LANDASAN TEORI}

Hal yang perlu dikembangkan dari anakusia dini adalah pemerolehan bahasa. Salah satu komponen pembelajaran bahasa adalah pemahaman kosakata dari bahasa Ingggris itu sendiri, di samping komponen komponen lainnya. Keterampilan berbahasa sangat dipengaruhi oleh perkembangan penguasaan kosa kata anak usia dini. Anak yang mampu berbahasa dengan baik maka sudah dipastikan kemampuan penguasaan kosa katanya juga baik.

Susilawati dan Suhardi (2016:113) mengatakan bahwa kosakata memiliki peram yang penting dalam proses berbahasa sebagai proses berpikir dan berkomunikasi. Sejalan dengan Tarigan (2011:2) bahwa kualitas keterampilan berbahasa seseorang bergantung pada kualitas penguasaan kosa katanya. Penilaian terhadap keterampilan berbahasa seseorang dapat dilihat 
dari pemilihan kosa kata yang digunakan dalam berbahasa. Semakin kaya kosakata yang kita miliki, semakin besar pula kemungkinan kita terampil berbahasa (Fitri, 2015:130).

Menurut Alex dan Achmad (2010:232) bahwa terdapat tiga hal yang dilakukan oleh seseorang untuk meningkatkan penguasaan kosa akata yaitu pemakaian kamus umum dan kamus sinonim dengan baik, memasukkan kata baru dalam bentuk tulisan atau lisan, membaca jenis tulisan sebanyak-banyaknya dalam upaya mencapai kosa kata dan kepekaan bahasa yang luas.

Java merupakan program yang dijalankan di berbagai komputer termasuk telepon genggam. Aplikasi ini dibuat oleh James Gosling yang tergabung di Sun Microsystem yang diliris 1995 merupakan bagian dari Oracle. Aplikasi java dikompilasi dalam p-code (bytecode) dan dijalankan pada berbagai Mesin Virtual Java (JVM) (id.Wikipedia.org/wiki/java). Aplikasi java digunakan untuk memainkan lagu-lagu melalui perangkat komputer yang digunakan untuk mengajarkan kosa kata baru.

\section{METODE PENELITIAN}

Jenis penelitian ini yaitu Penelitian Tindakan Kelas (PTK) yang dilaksanakan dalam dua siklus yaitu prasiklus, siklus I, dan siklus II. Bentuk proses pengkajian berdaur dua tahap, yaitu, Tahap Perencanaan, Tahap Tindakan, Observasi serta Refleksi. Teknik pengambilan sampel yang digunakan adalah purposive samping. Subjek dalam penelitian tindakan kelas ini dilakukan peserta didik RA At-Taqwa, Jakarta Pusat, tahun ajaran 2019/2020 kelompok A yang berusia 4--6 tahun. Siswa berjumlah 21 yang terdiri dari 15 laki-laki dan 6 perempuan.

Adapun tahap-tahap penelitian ini dilaksanakan untuk memperbaiki proses kegiatan belajar-mengajar dan meningkatan kualitas hasil belajar peserta didik. Penelitian ini menggunakan teori Kemmis dan Mc Taggart yang mencakup kegiatan perencanaan (planning), pelaksanaan (action), pengamatan (obsevasi), dan refleksi (reflection) atau evaluasi. Keempat tahapan ini akan dilakukan refleksi yang memungkinkan adanya pengulangan proses pengulang perencanaan hingga evaluasi pada siklus 2. Kegiatan ini dilaksanakan untuk memperbaiki dan menyempurnakan siklus yang dilakukan sebelumnya, sehingga dari perbaikan-perbaikan tersebut akan membuahkan hasil yang lebih baik.

Pada tahapan rancangan tindakan, dilakukan penentuan masalah atau peristiwa yang akan dimati sebagai fokus dari penelitian yang diikuti oleh pembuatan instrumen pengamatan untuk memantau selama tindakan dilaksanakan. Tahapan pelaksananaan adalah tahap implementasi dari apayang telah dirancang sebelumnya, dan pelaksanaanya dilakukan didalam kelas. Tahapan pengamatan adalah tahap yang dilaksanakan selama tindakan berlangsung, yang dilaksanakan oleh pengamatan atau observer. Tahapan refleksi adalah 
pengkoreksi dari apa yang telah terjadi pada waktu melaksanakan tindakan. Berdasarkan hasil refleksi tersebut peneliti dapat memperbaiki kekurangan-kekurangan yang terjadi selama tindakan. Dalam tindakan kelas, antara tindakan yang satu dengan yang lainnya saling berhubungan. Pada setiap tindakan terdapat fokus penelitian yang kemudian dilaksanakan dan selama pelaksanaanya dilakukan pengamatan. Hasil pengamatan kemudian dikaji sebagai tahap refleksi untuk tindakan selanjutnya.

\section{PEMBAHASAN}

\section{Pelaksanaan Tindakan}

Pelaksanaan penelitian tindakan kelas dimulai dari siklus pertama yang terdiri dari empat kegiatan yaitu perencanaan, pelaksanaan/tindakan, observasi dan refleksi. Apabila sudah diketahui letak dan keberhasilan dan hambatan dari tindakan yang dilaksanakan pada siklus pertama tersebut maka peneliti menentukan rancangan untuk siklus kedua. Kegiatan pada siklus kedua dapat berupa kegiatan yang sama dengan kegiatan sebelumnya yang ditunjukan untuk mengulangi kesuksesan atau untuk meyakinkan atau menguatkan hasil. Akan tetapi, umumnya kegiatan yang dilakukan pada siklus kedua mempunyai berbagai tambahan perbaikan dari tindakan sebelumnya, yang tentu saja ditunjukan untuk memperbaiki hambatan atau kesulitan yang ditemukan pada siklus pertama. Setiap siklus dalam penelitian ini terdiri dari empat tahapan, yaitu perencanaan, tindakan, observasi, dan refleksi. Adapun penelitian yang dilakukan adalah sebagai berikut:

a. Pra Siklus

Pada pertemuan pertama sebelum siklus dimulai, dilakukan pemberian tes awal kepada seluruh siswa, untuk mengetahui kemampuan awal siswa.Selain itu, guru juga memberikan sedikit penjelasan kepada siswa mengenai berbagai media pembelajaran, seperti mengenalkan lagu, dalam kegiatan belajar-mengajar.

b. Siklus I

Setelah melakukan evaluasi tindakan pra siklus maka, dilakukan tindakan I. Peneliti mengamati proses penerapan bernyanyi secara berulang-ulang pada anak RA At-Taqwa, Jakarta Pusat.Langkah-langkah siklus I adalah sebagai berikut:

1) Perencanaan

a) Mengidentifikasi dalam masalah-masalah khusus yang dialami pada siklus sebelumnya.

b) Membuat Rencana Kegiatan Harian.

c) Menyiapkan fasilitas untuk menyalakan aplikasi java seperti laptop dan proyektor. 
d) Menyiapkan lagu yang akan dinyanyikan dengan judul "balonku"

e) Menyiapkan lembar observasi untuk mengadakan evaluasi sebagai sarana untuk mengetahui kemampuan peserta didik.

2) Pelakanaan Tindakan

Kegiatan yang dilaksanakan tahap ini yaitu pengembangan rencana tindakan I dengan melaksanakan tindakan supaya lebih meningkatkan semangat belajar anak didik dalam kegiatan pembelajaran pemerolehan kosa kata melalui teknik bernyanyi pada aplikasi java, yang lebih direncanakan sebagai berikut :

a) Guru mengucapkan salam

b) Guru memimpin doa

c) Guru mendata kehadiran anak

d) Guru menyiapkan media aplikasi java

e) Guru memberilan penjelasan jalannya pembelajaran

f) Guru mencontohkan penggalan bait lagu tersebut di depan kelas

g) Anak mengucapkan lirik lagu secara berulang-ulang

h) Guru memberikan kesempatan kepada anak untuk bertanya mengenai kata baru yang belum jelas

i) Guru mengadakan tes lisan

j) Guru menutup pembelajaran dengan salam.

3) Pengamatan (Observasi)

Tahap observasi yang dilakukan ini untuk mengetahui kondisi kelas terutama keaktifan belajar anak dalam pembelajaran. Hasil pengamatan penelitian ini kemudian mencari permasalahan yang ada dan solusi pada waktu pembelajaran berlangsung.

4) Refleksi

Menilai hasil tindakan dengan meggunakan format lembar observasi anak. Kemudian melakukan evaluasi tindakan yang telah dilakukan.Menganalisis hasil pengamatan untuk memperoleh gambaran bagaimana dampak dari tindakan yang telah dilakukakan. Hal apa saja yang perlu diperbaiki sehingga diperoleh hasil refleksi kegiatan yang telah dilakukan.Hasil pengamatan dijadikan refleksi untuk rencana tindakan pada siklus kedua.

c. Siklus II

Kegiatan yang dilaksanakan tahap ini yaitu pengembangan rencana tindakan siklus II dengan melaksanakan tindakan supaya lebih meningkatkan semangat 
belajar anak didik dalam kegiatan pembelajaran kemampuan pemerolehan kosa kata melalui media aplikasi java menggunakan teknik bernyanyi, yang lebih direncanakan sebagai berikut. Langkah-langkah siklus II adalah sebagai berikut:

a) Perencanaan

1) Mengidentifikasi adalah masalah-masalah khusus yang dialami pada siklus sebelumnya.

2) Membuata Rencana Kegiatan Harian (RKH)

3) Menyiapkan media gambar dan kata dalam lirik lagu yang sesuai dengan penyampaian materi pokok bahasan

4) Menyiapkan lembar observasi untuk mengadakan evaluasi sebagai sarana untuk mengetahui kemampuan anak

b) Pelaksanaan Tindakan

Kegiatan yang dilaksanakan pada tahap ini yaitu pengembagan rencana tindakan II dengan melaksanakan tindakan supaya lebi menigkatkan semangat belaja anak didik dalam kegiatan pembelajaran kemampuan berbahasa melalui lirik lagu pada anak PAUD Putra PutriJakarta Utara yang lebih direncanakan sebagai berikut :

1) Guru mengucapkan salam

2) Guru memimpin doa

3) Guru mendata kehadiran anak

4) Guru menyiapkan media aplikasi java

5) Guru memberilan penjelasan jalannya pembelajaran

6) Guru menjelaskan materi pokok bahasan dalam pembelajaran lirik lagu kepada anak sambil mengenalkan kosa kata baru

7) Anak mengucapkan lirik lagu secara berulang-ulang

8) Guru memberikan kesempatan kepada anak untuk bertanya mengenai kata baru yang belum jelas

9) Guru mengadakan tes lisan

10) Guru menutup pembelajaran dengan salam

c) Pengamatan (Observasi )

Pada tahap ini mencatat semua proses yang terjadi dalam tindakan, mendiskusikan tentang siklus II yang telah dilakukan, mencatat keaktifan anak.

d) Refleksi 
Menilai hasil tindakan dengan menggunakan format lembar observasi anak, melakukan evaluasi tindakan yang telah dilakukan, dan menganalisis hasil pengamatan untuk memperoleh gambaran bagaimana dampak dari tindakan yang dilakukan. Hal apa sajayang perlu diperbaiki sehingga diperoleh hasil refleksi kegiatan yang telah dilakukan.

d. Observasi (Observing)

Tahap ini dilakukan observasi yang dilakukan untuk melakukan kondisi kelas terutama keaktifan belajar anak dalam pembelajara. Hasil pengamatan penelitian ini kemudian dicari permasalahan yang ada dan solusi pada waktu pembelajaran berlangsung.

\section{e. Refleksi (Refleksi)}

Dilakukan pengolahan dsn menganalisis data yang diperoleh pada siklus I. Evaluasi pada siklus I dilakukan dengan memberi lembar kerja kepada siswa disetiap akhir siklus serta pemberian angket kepada siswa untuk mengetahui nilai dan tanggapan siswa tentang proses belajar dengan menggunkan strategi pengamatan, dengan metode praktikum sebagai sarana dalam meningkatkan hasil belajar siswa.

\section{Paparan Proses dan Hasil Penelitian Pra Siklus}

Sebelum melakukan penelitian tindakan kelas, dilakukan pra siklus untuk melihat kemampuan anak dalam pemerolehan kosa kata, agar keberhasilan peneliti dapat terlihat jelas maka dilakukan pra siklus sebagai perbandingan sebelum dilakukan tindakan kelas dan sesudah tindakan kelas. Hasil observasi awal yang diperoleh dari pelaksanaan pengamatan pada pra siklus sebagai berikut. Pada 21 anak yang diteliti dalam penguasaan kosa kata sebanyak 10 anak belum berkembang untuk penguasaan kosa katanya atau dalam hal ini BB 47,6\%. Sebanyak 6 anak dalam hal penguasaan kosa kata masih berkembang atau MB 28,6\%. Sebanyak 3 anak dalam hal penguasaan kosa kata berkembang sesuai harapan atau BSH 14,2. Kemudian sebanyak 2 anak dalam penguasaan kosa kata berkembang sangat baik atau BSB 9,5. Hasil penelitian di atas diketahui bahwa penguasaan bahasa dalam hal ini kosa kata anak masih butuh peningkatan yang lebih dalam lagi. Maka dari itu peneliti bersama guru merencanakan untuk dapat melaksanaan penelitian siklus 1 menggunakan media aplikasi Java melalui teknik bernyanyi.

\section{Paparan Proses dan Hasil Penelitian Siklus I}

Observasi pada siklus I pengembangan kemampuan kosa kata anak menunjukan peningkatan hasil yang baik. Pencapaian kemampuan kosa kata anak menggunakan media aplikasi Java melalui teknik bernyanyi sebagai berikut: Belum Berkembang (BB) 5 anak atau 
23,8\%, Mulai Berkembang (MB) 9 anak atau 42,9\%, Berkembang Sesuai Harapan (BSH) 4 anak atau 19\%, Berkembang Sangat Baik (BSB) 3 anak atau 14,3\%. Hasil persentase perkembangan berbahasa anak melalui lirik lagu pada siklus I. Berdasarkan hasil observasi dan kegiatan pencatatan lapangan, peneliti dan guru melakukan analisis terhadap proses pembelajaran dalam kegiatan melafalkan lagu yang diterapkan dalam pengembangan kemampuan berbahasa anak.

Analisis dilakukan dengan cara berdikskusi, mengevaluasi proses pembelajaran yang telah dilakukan,serta melihat kekurangan-kekurangan yang terjadi dapat diperbaiki pada pertemuan selanjutnya. Hasil refleksi yang dilaksanakan pada siklus I sebagai berikut:

a. Pelaksanaan kegiatan berbahasa anak melalui lirik lagu sesuai dengan RPPH.

b. Masih ada anak yang belum dapat berbahasa dengan baik dan benar dalam kosa kata.

c. Waktu pembelajaran kurang efesien.

d. Dikarenakan masih ada siswa yang kurang fokus.

\section{Paparan Proses dan Hasil Penelitian Siklus II}

Perencanaan tindakan yang akan dilakukan pada siklus II didasarkan pada hasil observasi dan refleksi siklus I.Pada dasarnya kegiatan bernyanyi pada tindakan siklus II ini tidak jauh berbeda dengan siklus I. Pertemuan kedua dan ketiga siklus II peneliti menggunakan tema binatang dengan sub tema "Pada Hari Minggu" dimana ada pengenalan terhadap binatang pada penggalan liriknya. Hasil observasi peneliti pada siklus II mengalami peningkatan sebagai berikut: Belum Berkembang (BB) 0 anak atau 0\%, Mulai Berkembang (MB) 5 anak atau 23,8\%, Berkembang Sesuai Harapan (BSH) 5 anak atau 23,8\%, Berkembang Sangat Baik (BSB) 11 anak atau 52,4\%.

Kemampuan yang meningkat pada setiap aspek kosa kata yang dilakukan pada prasiklus, meningkat pada siklus I, dan siklus II. Hal ini sesuai dengan harapan peniliti dimana setiap siklus terdapat peningkatan dalam pemerolehan bahasa anak. Penerapan metode peningkatan berbahasa anak usia dini melalui nyanyian dinilai sangat efektif untuk memingkatkan pembendaharaan kata pada anak.

Anak merasa sangat nyaman dan tidak lagi bosan dengan penggunaan metode ceramah seperti biasa. Anak menjadi antusias jika penggunaan metode belajar sangat bervariasi pada setiap pertemuannya. Anak menjadi lebih mudah memahami hal yang ingin disampaikan oleh guru, materi mudah terserap, sehingga meningkatkan proses berbahasa pada anak.

\section{E. SIMPULAN DAN SARAN}

Simpulan penelitian ini yaitu pada siklus I, penguasaan kosa kata BB 11\%, MB 52\%, BSH $28 \%$, BSB $21 \%$. Hasil siklus II naik seperti apa yang sudah diharapkan yaitu kenaikan 
kosa kata anak sebanyak lebih dari 50\%, BB 0\% MB 5\%, BSH 26\%, BSB 74\%. Program java layak untuk digunakan sebagai media belajar, media belajar ini mampu untuk meningkatkan kemampuan kosa kata anak.

Peningkatan kosa kata anak usia dini di RA-At-Taqwa, maka peneliti mengemukakan saran-saran yang bermanfaat bagi peneliti selanjutnya, tenaga pendidikan, dan bagi sekolah, sebagai berikut:

1. Kegiatan pemerolehan kosa kata lebih baik dilakukan sedini mungkin

2. Para guru diharapkan agar lebih memprioritaskan pengajaran bahasa Indonesia khusus untuk memperoleh kosa kata anak usia dini.

3. Guru hendaknya menggunakan strategi dalam mengajar terutama dalam pengajaran bahasa Indonesia, untuk pemerolehan kosa kata media yang sesuai dengan zaman saat ini adalah yang berhubungan dengan teknologi.

4. Peran kepala sekolah dalam menerapkan pentingnya penguasaan dan penggunaan aplikasi java yang disesuaikan dengan kemajuan IPTEK pada saat ini perlu diterapkan kepada semua guru dan tenaga pendidik di era revolusi 4.0.

5. Bagi peneliti berikutnya, banyak hal yang dapat dikembangkan sebagai penelitian lanjutan dari penelitian ini maka harapan penulis hasil penelitian ini dapat dijadikan sebagai inspirator untuk terus-menerus berinovasi dalam pendidikan.

\section{DAFTAR PUSTAKA}

Alex \& Achmad, H. (2010). Bahasa Indonesia untuk perguruan tinggi. Jakarta: Kencana Prenada Media Group

Fitri, Rahayu. 2015. Kontribusi Minat Baca dan Penguasaan Kosakata terhadap Kemampuan Membaca Pemahaman Siswa Kelas X SMA Negeri 1 Padang Ganting Kabupaten Tanah Datar. Jurnal Gramatika. STKIP PGRI Sumatera Barat. Vol 1 No 2 Hal 128-140 $\quad$ http://ejournal.stkip-pgri-sumbar.ac.id/index.php/jurnalgramatika/article/view/1233/pdf

Sallaby, A. F., Utami, F. H., \& Arliando, Y. (2015). Aplikasi Widget Berbasis Java. Jurnal Media Infotama.

Susilawati, Tjatur Marti, Dan Suhardi. 2016. Hubungan Antara Penguasaan Kosakata dan Ketepatan Menemukan Gagasan dengan Keterampilan Membaca Pemahaman. Jurnal Lintera. Universitas Negeri Yogyakarta. Vol 3 Nomor 12016 Hal 112-121 https://journal.uny.ac.id/index.php/ljtp/article/view/8796/7641

Tarigan, Henry Guntur. 2011. Pengajaran Kosakata. Bandung: Angkasa. 